AperTO - Archivio Istituzionale Open Access dell'Università di Torino

\title{
Vegetative regeneration of beech coppices for biomass in Piedmont, NW Italy
}

\section{This is the author's manuscript}

Original Citation:

Availability:

This version is available http://hdl.handle.net/2318/1657723

since 2018-01-16T14:41:39Z

Published version:

DOI:10.1016/j.biombioe.2017.10.018

Terms of use:

Open Access

Anyone can freely access the full text of works made available as "Open Access". Works made available under a Creative Commons license can be used according to the terms and conditions of said license. Use of all other works requires consent of the right holder (author or publisher) if not exempted from copyright protection by the applicable law. 


\title{
Vegetative regeneration of beech coppices for biomass in Piedmont, NW Italy
}

\author{
Giorgio Vacchiano ${ }^{1 *}$, Roberta Berretti ${ }^{1}$, Pierpaolo Brenta $^{2}$, Fabio Meloni ${ }^{1}$, Renzo Motta ${ }^{1}$, Antonio \\ Nosenzo ${ }^{1}$, Pier Giorgio Terzuolo ${ }^{2}$ \\ 1 University of Turin, DISAFA. Largo Braccini 2, 10095 Grugliasco (TO), Italy \\ 2 Istituto per le Piante da Legno e l'Ambiente IPLA S.p.A. Corso Casale 476, 10132 Torino, Italy \\ * corresponding author. giorgio.vacchiano@unito.it, tel +39 011 6705536, fax +39 0116705556
}

\begin{abstract}
Interest in coppices is growing due to the need to replace fossil fuels with renewable energy sources. In Italy, beech covers one million hectares, half of which originated by coppicing. This study tested which factors drive the presence and growth of beech resprouts, with a focus on fertility, cutting intensity, age, and size at time of coppicing.

We analyzed 509 stools in 24 stands coppiced between 1 and 26 years before sampling. We fitted Generalized Linear Mixed Models of the probability of sprouting and height of the tallest resprout for each stool as a function of elevation, slope, aspect, bedrock, precipitation, temperature, age at coppicing, time since coppicing, residual shoot density, the sum, average and coefficient of variation of the diameter of cut shoots, and type of stool treatment.

Of all harvested stools, 249 (49\%) had sprouted with an average of 7.6 resprouts per stool. Height of the tallest resprout on each stool ranged from 3 to $800 \mathrm{~cm}$, mainly as a function of time since coppicing. Resprout mortality was on average $1.4 \%$ per plot. Sprouting decreased with decreasing site fertility, increasing precipitation, and increasing size of cut stems. Leaving one or more shoots on the stool after felling produced a high proportion of sprouting stools (82\%).

Although based on a limited sample, our quantitative analysis of the driving factors of sprouting in beech can be used to support silvicultural decisions in over-mature beech coppices, and to optimize trade-offs between ecosystem services such as biomass production, biodiversity, and hydro-geologic protection.
\end{abstract}

Keywords: biomass, Fagus sylvatica L., forest management, sprouting

\section{Highlights:}

- Forest coppicing allow to replace fossil fuels with renewable energy sources

- We tested which factors drive the probability and vigor of beech sprouting in the Italian Alps

- Sprouting decreased with poor soils, higher precipitation and increasing stool size

- When one or more shoots were left, $82 \%$ of the stools sprouted

- This evidence can be used to sustainably manage beech coppices for biomass 


\section{Introduction}

Coppicing is a silvicultural treatment that takes advantage of the ability of broadleaves to reproduce clonally [1]. When a stem or root is damaged by natural disturbance or cut, changes in hormonal controls prompt root collar buds to generate a new resprout [2]. Such ability varies among species [3] and can be maintained indefinitely or lost with ageing [4].

Since regeneration by coppicing is relatively easy to obtain, and usually grows faster than seedlings thanks to the reserves stored in the root systems of the living stools [5], coppicing has been one of the most common forms of forest management, mostly preferred when seed regeneration is impractical for time, money, or site constraints, and to obtain a fast and steady production of firewood or charcoal [6]. To compensate for the progressive exhaustion of root reserves and consequent mortality of whole stools, and to mitigate the loss of soil and nutrients, clearcut coppicing has often been replaced by sheltered coppicing [7], selection coppicing [8], or maintained under a seed-regenerated overstory. In Europe, coppicing has historically been more common in southern and eastern countries, e.g., Italy, Spain, Bulgaria, or Serbia, but has recently declined due to depopulation of rural areas and the spreading of fossil fuels, leading to an increase of stored or neglected coppices [9]. To avoid growth stagnation and mechanical instability, steer the forest towards a more "natural" structure, and promote the harvest of larger and more valuable timber, many administrations subsidized the conversion of stored coppices to high forest $[1,10,11]$, while most private-owned coppices were neglected. In recent years, however, the interest in coppices has been rekindled due to the need to replace fossil fuels with renewable energy sources [12-14]. Above being a source of bioenergy, coppices can sustain effectively other ecosystem services such as biodiversity conservation [15-18, but see also 19], protection from natural hazards [20], provision of non-wood forest products [21], or climate change resilience [22].

The key factor in successful coppice management restoration, whether for nature conservation or for economic reasons, is the permanence of the capacity of trees to sprout from their stool. However, there is still very little quantitative information on sprouting ability and its drivers in the main European tree 
6

species. For some of them, sprouting success is known to be limited when coppicing is carried out on older stems $[8,23,24]$. Beech (Fagus sylvatica L.), one of the most widespread and commercially important forest trees in Europe, is one of such species. In non-managed stands dominated by species of the genus Fagus, the incidence of clonal reproduction is often greater where disturbances are more severe [25]. Studies on such survival benefits of sprouting in natural systems exist $[15,26]$, but research exploring the contribution of vegetative reproduction in managed stands are still scarce.

Beech coppices are widespread in Southern European mountains, and have been used extensively to provide firewood and charcoal. However, beech has been showed as one of the weakest sprouters among temperate broadleaves, especially when the temporal span of such sprouting ability is concerned [27]. In Italy, beech covers more than one million hectares (10\% of total forest cover), half of which originated by coppicing [28]. In Alpine regions such as Piedmont (NW Italy) the share of coppices among beech forests reaches $90 \%$. Here, the recent regional Forest Management Act prohibited coppicing beech stands older than 40 years. To support decisions on the ecological and economic sustainability of maintaining coppicing, and to test legal disposition against ecological evidence, we carried out an analysis of vegetative regeneration of beech coppices in Piedmont. The aim was to test which factors ensure a successful sprouting of beech stools, with a specific attention on fertility, cutting intensity, age and size at the time of coppicing.

\section{Material and methods}

We analyzed 24 beech coppice stands in 13 municipalities of Piedmont (Fig. 1). Stands were within an elevation range of 850-1350 $\mathrm{m}$ a.s.1.; mean annual temperature and precipitation ranged from 6.4 to 11.0 ${ }^{\circ} \mathrm{C}$ and from 1120 to $2315 \mathrm{~mm}$, respectively (interpolated weather station data for the period 1951-86 [29]). At all sites, soil water regime was classified as udic; soil type and soil nutrient supply were note measured directly, but site fertility was described by a dummy variable ranging from 1 (poor) to 4 (very 
good), following a region-wide forest cover type classification [30]. All stands had been coppiced between 1 and 26 years before sampling. Data on tree density before and after coppicing were available from local forest management records; in absence of any other information, we assumed that all stems had originated as shoots in the original stands. Harvest intensity was defined as the relative change in the number of shoots before and immediately after coppicing (Table 1). Coppicing was carried out as either clearcut (one site, harvest intensity $=100 \%)$, coppice-with-standards $(72-95 \%, 15$ sites), or conversion to high forest (61-82\%, 8 sites); no selective coppices were present.

[Figure 1 here]

Stands ranged in size from 0.8 to 4.2 ha, as a result of the extreme fragmentation of privately owned forests such as beech coppices in Northern Italy. In each stand we established a circular sampling plot (radius $=8-14 \mathrm{~m}$, proportional to tree density) centered on randomly extracted coordinates within the stands (making sure that the whole plot area was contained within the stand limits). In each plot we recorded slope, aspect, and visually estimated canopy cover. For each stool in the plot, we counted all cut and uncut shoots, and all live and dead resprouts (i.e., shoots that we could confidently classify as having sprouted after the cut), and measured their diameter at stump height, origin (root or stem sprouting), and height (Table 1). We estimated the age of the stand at the time of coppicing by averaging tree ring counts from 3-5 exposed stools per plot. We also estimated the age of the resprouts by averaging the ring counts from 3-5 increment cores taken from each resprout diameter class.

We defined as "sprouting" all stools with at least a living resprout at the time of survey, and computed resprout mortality as the relative frequency of dead over all resprouts. These figures include mortality due to all causes (e.g., competition or natural disturbance), but do not account for resprouts that have died and fallen from the stool. The frequency of sprouting stools is therefore a conservative estimate. 
117

1

$118^{2}$

4

119

6

120

8

$121 b^{9}$

11

1222

13

124

16

1247

18

1259

21

1262

23

244
25

26
128

28

1209

30

1313

33

1334

35

136

38

1333

40

1341

43

1354

45

1346

47

$134 \%$

50

1381

52

1303

55

1406

57

1459 60

61

62

63

64

65

We fitted Generalized Linear Mixed Models (GLMMs) of the probability of sprouting ( 0 or $1, n=509$ stools) and height of the tallest resprout ( $n=249$ stools with live resprouts), which has been often found to correlate with future resprout survival [31]. GLMMs allowed us to accommodate non-independent observations (random variable =plot), non-normality and heterogeneity of the response, by using a binomial and lognormal distribution to model the probability of sprouting and the height of the tallest resprout, respectively. Independent variables included slope, bedrock (granite/acidic or limestone), annual precipitation, mean annual temperature, age at coppicing, time since coppicing, the mean and coefficient of variation of the diameter of cut shoots, and type of stool treatment (total or partial cut) (Table 1). Predictors were filtered for collinearity using variance inflation factors (VIF) thresholds (predictors were excluded if VIF >4). All models were optimized including only significant predictors and successfully scrutinized for overdispersion, normality of random factors, and residual patterns. Goodness-of-fit was assessed by the marginal (fixed factors) and conditional (fixed and random factors) coefficient of determination $\mathrm{R}^{2}$ for GLMMs [32,33], computed by the function r.squaredGLMM in the MuMIn package for R [34].

\section{Results}

The stands were coppiced at an age of 35 to 55 years $\left(25^{\text {th }}, 50^{\text {th }}, 75^{\text {th }}\right.$ percentiles: $40-45-50$ years, respectively). Average shoot density before coppicing was in a range of 969-3550 trees ha $^{-2}(1524-$ $2134-2383)$, and harvest intensity was in a range of 61-100\% (70\%-79\%-90\%). Of all 509 harvested stools, 249 (49\%) had sprouted a total of 2163 new resprouts (range: $0-100 \%$ of sprouting in each plot), with an average of 7.6 resprouts per stool (range: $0.3-18.4$ ). Only $5 \%$ of them sprouted from roots. Six out of 24 plots experienced resprout mortality (average: 1.4\%, range: 1-17\%). Except for one recently treated plot where no resprouts existed yet at the time of sampling, the height of the tallest resprout in the plot was significantly correlated with time since coppicing (Pearson's $R=0.66, \mathrm{p}<0.001$ ). The average age of resprouts was also correlated to time since coppicing $(\mathrm{R}=0.86, \mathrm{p}<0.001)$ but the two 
142

1

$143_{3}^{2}$

4

144

6

145

8

$14 \%$

11

$14 \mathbb{2}$

13

148

16

149

18

$150^{9}$

21

15212

23

1524

26
1537

28

154

30

1531

33

1564

35

$15_{37}^{36}$

38
1539

40

1591

42

$10_{44}^{3}$

45

1646

47

162

50

1631

52

163
54

165

57

1688

59

60

61

62

63

64

65

variables did not match perfectly, with a difference of 0-13 years between time since coppicing and average age of resprouts. Current canopy cover ranged from 20 to 100\% (average: 55\%, correlation with time since coppicing: $\mathrm{R}=0.58, \mathrm{p}=0.003$ ), and tended to saturate after about 15 years from coppicing. (Fig. 2).

At the plot level, both the proportion of sprouting stools and maximum resprout height were weakly correlated to decreasing residual shoot density $(R=-0.45$ and $-0.33, p=0.03$ and 0.14 , respectively) (Fig. 3). The low significance of the correlation between height and residual density has to do with the fact that age since coppicing is not factored in the analysis, indicating the need for a multiple regression approach. At the stool level, both the number of resprouts per stool and height of tallest resprout decreased with decreasing site fertility (Fig. 4), although the robustness of the correlation is somehow limited by the categorical classification of fertility. However, since fertility and bedrock were highly collinear $(\mathrm{R}=0.85)$, we decided to use only the second variable in GLMMs.

[Figure 2 here]

[Figure 3 here]

[Figure 4 here]

The model for probability of sprouting explained $41.2 \%$ of the total variance in the data (marginal $\mathrm{R}^{2}$ : $26.4 \%$ from fixed factors only; dispersion parameter $=0.86$ ). The significant variables were presence/absence of shoots left alive on the stool, mean diameter of cut shoots, age at the time of coppicing, and precipitation (Table 2). Sprouting decreased with increasing size of cut shoots (80\% of the those $>40 \mathrm{~cm}$ in diameter did not resprout) and increasing precipitation, and increased with increasing age at time of coppicing (Fig. 5); the presence of live shoots on the stool improved the probability of sprouting by $20-25 \%$ (Fig. 6). When one or more stools were left on the stool after felling, $82 \%$ of the stools sprouted. 
[Table 2 here]

[Figure 5 here]

[Figure 6 here]

The model for height of tallest resprout explained $88.9 \%$ of the total variance (marginal $\mathrm{R}^{2}: 62.2 \%$ ). The significant variables were annual precipitation, bedrock, and time since coppicing (Table 3). Age at time of coppicing was, as expected, the dominant driver of maximum resprout height (Fig. 7). However, height also decreased significantly with increasing annual precipitation, and on acidic bedrocks (Fig. 8).

[Table 3 here]

[Figure 7 here]

[Figure 8 here]

\section{Discussion}

Knowledge about coppicing of European beech stands has a long history in both textbook and operational silviculture [35]. The two main results reported in this paper are not new to the forester community, i.e., that larger shoots are less successful in sprouting due to faster desiccation of the cut stem, and that leaving a shoot on the stool acting as sap sucker keeps the stool tissues vital. However, such knowledge got somewhat obsolete in last decades and very few peer reviewed contributions exist on the topic. Having such popular knowledge confirmed and detailed by the main quantitative results of this paper is of high interest for managers.

Despite the limited sample size and the use of some non-quantitative or partially subjective measurement due to data limitations (e.g., bedrock, fertility, canopy cover), some clear trends emerged. In managed stands from this study, beech sprouting was influenced by stem diameter, age at the time of 
192

1

193

4
194

6

195

8

$19 \%$

11

$19 \mathbb{R}$

13

1984

16

199

18

20190

21

2012

23

$20_{22}^{24}$

2036

28

2089

30

2035

33

2064

35

2036

38

2089

40

2049

43

2144

45

2146

47

2148

50

21531

52

53

$2 \frac{54}{55}$

56

2157

58

250

61

62

63

64

65

coppicing, presence of uncut shoots, time since coppicing, annual precipitation and bedrock. The effect of size at the time of coppicing has been documented by previous studies [4,36]; small stools are younger and their resprouts may be more vigorous [37]. This is consistent with anecdotal knowledge of European foresters [38] and with studies from other species of the Facageae family, e.g., on North American oaks, showing a decline in the number of resprouts and a lower height growth with increasing diameter at the time of coppicing $[39,40]$. Such behavior may be related to failure of hidden epicormic buds to develop into new resprouts due to the increasing physical resistance of the bark as diameter increases with age [41].

All other things being equal, age of the shoot at the time of coppicing had a positive effect at the individual level, but a negative effect at the stand level; if mean age was $<40$ years, on average $70 \%$ of stools sprouted, but only $50 \%$ if mean age was $>50$ years. Other European species show a positive effect of age at time of coppicing on sprouting, e.g., hornbeam [42], as young resprouts can benefit from the mature root system of a parent tree [43]. The ability of stools to sprout at a later age is the main obstacle for coppice restoration, as many coppice stands have been either neglected, or converted to high forest several decades ago. These results are generally consistent with provisions by regional forest regulations that, in many Italian regions, forbid coppicing of beech beyond 40 years of age.

In our study, more productive sites - those with limestone bedrock rather than acidic - were associated to an increased probability of sprouting, other factors being equal. Relative to the overall figure (70\%), stands on the most fertile sites (eutrophic beech forest cover type) showed a much higher proportion of sprouting stools at age $<40$ years $(91 \%)$. This suggests the relevance of resource allocation mechanisms, as abundant non-structural carbohydrates can be preferentially allocated to bud growth rather than shoot biomass [44], but data on this trait are largely lacking [45].

Regarding the role of climate, high precipitation and moisture may cause the bark to partly fall off from the stool in shade-tolerant species characterized by a thin bark such as beech, consequently killing or damaging the buds [31]; in sites where annual precipitation was higher than $1500 \mathrm{~mm}$ we observed total 
217

1

2

$218_{4}^{3}$

$219^{5}$

7

$22 \sigma^{8}$

10

2211

12

22128

14

$2 \frac{15}{23}$

17

2218

19

$225^{\circ}$

22

2268

24

25

220

28

2280

30

2241

233

35

23316

37

38

$23 \%$

41

2312

43

2344

46

2357

48

2349

51

53

54

2350

57

2358

59

240

61

62

63

64

65

decay of stools as soon as eight years after cutting.

Finally, a very strong effect on sprouting probability was played by the presence of one or more uncut shoots on the stool. This has the advantage of slowing down stool decay and avoid drying out of the cut surface. All else being equal, stools with uncut shoots (even if these had poor growth and form) showed a higher probability of sprouting, a higher number of resprouts and a better average resprout growth.

This result is consistent with earlier evidence from selection coppices, where the number and growth of resprouts after a rotation of 20 years was higher than in clearcut coppices or coppices with standards of the same age [8]. We therefore suggest that sprouting ability can be improved by retaining at least one shoot per stool uncut, especially when restoring coppice in unfavorable situations (poor fertility or late age).

Similar variables appeared to influence the growth of resprouts after the cut. Beyond the obvious influence of time since coppicing, height of the tallest resprout was positively influenced by nutrient availability (limestone bedrock), and negatively by precipitation. Warmer aspect (south-facing) were expected to improve resprout growth, especially due to the sensitivity of young resprouts to late frost, but the effect was not significant (albeit positive).

Another driver of resprout growth was residual shoot density. At the stand level, shading from increasing stand density markedly affected stool sprouting and growth of the resprouts: the average proportion of sprouting stools was $69 \%$ when residual shoot density was $<400$ trees per hectare, but only $32 \%$ above that threshold (Fig. 3). Trees that are, or have to be, left standing as a seed source to compensate for stool exhaustion, also limit the amount of light that reaches the forest floor, and may therefore either favor or hinder the regeneration depending on their density [41].

This work, albeit conducted on a limited sample size, confirmed that increasing age and size at the time of coppicing are associated to a decline in sprouting ability of European beech. Over-mature coppices suffer from detrimental physiological changes, a reduction in re-sprouting ability, and increased 
241

1

242

$243^{4}$

6

244

8

10

$24{ }_{1} 1$

12

13

2464

15

247

18

2489

20

240

23

24

2545

26

$2521^{2}$

29

2530

31

$2 \xi_{33}^{32}$

2535

36

2537

39

2540

41

2542

43

$25 \frac{44}{45}$

46

47

2598

49

25

52

2653

54

$2 \underset{52}{56}$

57

2638

59

60

61

62

63

64

65

mechanical failure that substantially decreases their longevity [46]. The recommended maximum age for coppicing beech is 40 years. However, leaving one shoot uncut on the stool significantly improves sprouting. All else being equal, residual shoot density, site fertility and climate were also found to play an important role.

\section{Conclusions}

We showed how beech sprouting in the western Italian Alps decreases with poor soils, higher precipitation, and increasing stool size and age. An effective measure to preserve vegetative regeneration ( $82 \%$ of cases) is to leave one or more shoots uncut.

Such evidence can support silvicultural decisions in overmature beech coppices, which still represent present an unsolved silvicultural dilemma. When the choice must be made between abandonment, active conversion into high forest, mixed regeneration systems [47], or restoration of clearcut or selection coppicing, forest managers should carefully examine stand age, climate, soil, and site characteristics. Old coppices on poor soils and humid climates exhibit a poor sprouting capacity, and are the first candidates for conversion to high forest. On the other hand, coppices on more fertile soils that have not yet reached 40-50 years of age can be targeted for a continuation or restoration of vegetative regeneration aimed at the provision of sustainable energy wood, provided that one or more live shoots are left on the stool.

In a warming world, over-mature and neglected coppices are also more vulnerable to climatic stress and xylem cavitation $[48,49]$. Therefore, restoration of coppices has the potential to increase forest resilience in all broadleaves forests at risk from e.g. drought or pests - that put especially large, old trees at risk of death faster than they can be replaced by seed regeneration - and still sustain key ecosystem services such as biodiversity, biomass production, and hydrogeologic protection. 
Acknowledgments

26 $\frac{4}{5}$ The authors support the campaign \#ricercaprecaria for the full implementation of the European Charter 6

for Researchers and the acknowledgement of all researchers as workers, and the Change.org petition

"Salviamo la ricerca italiana" (https://www.change.org/p/salviamo-la-ricerca-italiana) for the increase of research funding in Italy to the levels requested by the EU Lisbon strategy.

$2 \frac{14}{15}$

16

2717

18

270

\section{Conflict of interest}

The authors declare no conflict of interest and compliance with the current laws of the country in which 21 field measurement were performed. 


\section{References}

[1] Buckley GP. Ecology and management of coppice woodlands. London, UK: Chapman \& Hall; 1992.

[2] Vesk PA. Plant size and resprouting ability: trading tolerance and avoidance of damage? J Ecol 2006;94(5):1027-1034.

[3] Matula R, Svátek M, Kůrová J, Úradníček L, Kadavý J, Kneifl M. The sprouting ability of the main tree species in Central European coppices: implications for coppice restoration. Eur J For Res 2012;131:1501-1511.

[4] Del Tredici P. Sprouting in temperate trees: a morphological and ecological review. Bot Rev 2001;67(2):121-140.

[5] Zhu WZ, Xiang JS, Wang SG, Li, MH. Resprouting ability and mobile carbohydrate reserves in an oak shrubland decline with increasing elevation on the eastern edge of the Qinghai-Tibet Plateau. For Ecol Manag 2012; 278(8):118-126.

[6] Vacchiano G, Garbarino M, Lingua E, Motta R. Ecology of mountain forest ecosystems in the Italian Apennines. For Ecol Manag 2017;in press.DOI 10.1016/j.foreco.2016.10.33

[7] Stewart PJ. Coppice with standards: a system for the future. Commonw For Rev 1980;59:149-154.

[8] Coppini M, Hermanin L. Restoration of selective beech coppices: a case study in the Apennines (Italy). For Ecol Manag 2007;249(1):18-27.

[9] Amorini E, Fabbio G, Bertini G. Stand dynamics of a beech coppice beyond the rotation age and under conversion into high forest. Ann Silvic Res 2010;36:151-172.

[10] Ciancio O, Corona P, Lamonaca A, Portoghesi L, Travaglini D. Conversion of clearcut beech coppices into high forests with continuous cover: A case study in central Italy. For Ecol Manag 2006; 224(3):235-240.

[11] Mattioli W, Ferrari B, Giuliarelli D, Mancini LD, Portoghesi L, Corona P. Conversion of mountain beech coppices into high forest: an example for ecological intensification. Environ

Manag 2015;56(5):1159-1169. 
302

1

$303_{3}^{2}$

304

6

305

9

306

11

3012

13

3018

16

309

18

3109

21

3 bl

23

$3 \frac{24}{25}$

26

28

$3 R 9$

30

$3 \sqrt{31}$

33

31364

35

$3 \mathrm{I}_{3}^{3.6}$

38

3138

40

319

43

3244

45

3246

47

3248

50

3531

52

3254

55

3256

57

58

59

60

61

62

63

64

65

[12] Hall JP. Sustainable production of forest biomass for energy. For Chron 2002; 78(3):391-396.

[13] Jansen P, Kuiper L. Double green energy from traditional coppice stands in the Netherlands.

Biomass Bioenerg 2004;26(4):401-402.

[14] McKenney DW, Yemshanov D, Fraleigh S, Allen D, Preto F. An economic assessment of the use of short-rotation coppice woody biomass to heat greenhouses in southern Canada. Biomass Bioenerg 2011;35(1):374-384.

[15] Vacik H, Zlatanov T, Trajkov P, Dekaniæ S. Role of coppice forests in maintaining forest biodiversity. Silva Balc 2009;10(1):35-45.

[16] Negro M, Vacchiano G, Berretti R, Chamberlain DE, Palestrini C, Motta R, et al. Effects of forest management on ground beetle diversity in alpine beech (Fagus sylvatica L.) stands. For Ecol Manag 2014;328:300-309.

[17] Müllerová J, Hédl R, Szabó P. Coppice abandonment and its implications for species diversity in forest vegetation. For Ecol Manag 2015;343:88-100.

[18] Kirby KJ, Buckley GP, Mills J. Biodiversity implications of coppice decline, transformations to high forest and coppice restoration in British woodland. Folia Geobotanica 2017;in press. doi:10.1007/s12224-016-9252-1.

[19] Vacchiano G, Meloni F, Ferrarato M, Freppaz M, Chiaretta G, Motta R, Lonati M. Frequent coppicing deteriorates the conservation status of black alder forests in the Po plain (northern Italy). For Ecol Manage 2016; 382: 31-38

[20] Jancke O, Dorren LK, Berger F, Fuhr M, Köhl M. Implications of coppice stand characteristics on the rockfall protection function. For Eco Manag 2009;259(1):124-131.

[21] Kobayashi T, Kitahara M, Ohkubo T, Aizawa M. Relationships between the age of northern Kantou plain (central Japan) coppice woods used for production of Japanese forest mushroom logs and butterfly assemblage structure. Biodivers Conserv 2010;19(8):2147-2166. 
326

1

327

324

6

329

8

$330^{9}$

11

3312

13

$33 \frac{14}{15}$

16

3313

18

$33 \frac{19}{20}$

21

33252

23

336

26
3377

28

3389

30

$33 \frac{31}{32}$

33

3439

35

$3 \frac{35}{36}$

38

3439

40

3431

43

3444

45

3456

47

348

50

3451

52

$3 \frac{53}{54}$

55

3456

57

3599

60

61

62

63

64

65

[22] Gavinet J, Prévosto B, Fernandez C. Introducing resprouters to enhance Mediterranean forest

resilience: importance of functional traits to select species according to a gradient of pine density. J Appl Ecol 2016;in press. doi:10.1111/1365-2664.12716.

[23] Atwood CJ, Fox TR, Loftis DL. Effects of alternative silviculture on stump sprouting in the southern Appalachians. For Ecol Manag 2009;257(4):1305-1313

[24] Harmer R, Howe J. The silviculture and management of coppice woodlands. Edinburgh, UK: The Forestry Commission;2003.

[25] Morris AB, Small RL, Cruzan MB. Variation in frequency of clonal reproduction among populations of Fagus grandifolia Ehrh. in response to disturbance. Castanea 2004;69(1):38-51.

[26] Zywiec M, Holeksa J. Sprouting extends the lifespan of tree species in a seedling bank: 12-year study. For Ecol Manag 2012;284:205-212.

[27] Clarke PJ, Lawes MJ, Midgley JJ, Lamont BB, Ojeda F, Burrows GE, et al. Resprouting as a key functional trait: how buds, protection and resources drive persistence after fire. New Phytol $2013 ; 197: 19-35$.

[28] Nocentini S. Structure and management of beech (Fagus sylvatica L.) forests in Italy. iForest Biogeosciences and Forestry 2009;2:105-113.

[29] Biancotti A, Bellardone G, Bovo S, Cagnazzi B, Giacomelli L, Marchisio C. Distribuzione regionale di piogge e temperature. Torino, IT: Regione Piemonte e Università degli Studi di Torino; 1998.

[30] Camerano P, Gottero F, Terzuolo P, Varese P. Tipi forestali del Piemonte. Torino, IT: Regione Piemonte; 2008.

[31] Leonardsson J, Götmark F. Differential survival and growth of stumps in 14 woody species after conservation thinning in mixed oak-rich temperate forests. Eur J For Res 2015;134(1):199-209.

[32] Nakagawa S, Schielzeth H. A general and simple method for obtaining $\mathrm{R}^{2}$ from Generalized Linear Mixed-effects Models. Methods Ecol Evol 2013;4:133-142. 
351

1

352

352

6

354

$355^{9}$

11

3516

13

$35_{15}^{14}$

16

3518

18

3599

21

3620

23

364

26

28

3839

30

3631

33

3634

35

3636

38

3689

40

3681

43

3694

45

3776

47

3748

50

372

52

3753

55

3756

57

578
59

60

61

62

63

64

65

[33] Johnson PCD. Extension of Nakagawa \& Schielzeth's R ${ }^{2}$ GLMM to random slopes

models. Methods Ecol Evol 2014;5:44-946.

[34] Bartoń K. MuMIn: Multi-Model Inference. R package version 1.15.6. 2016. https://CRAN.Rproject.org/package=MuMIn.

[35] Buckley GP, Mills J. Coppice silviculture: from the Mesolithic to the 21st century. In: Kirby K, Watkins C (eds). Europe's Changing Woods and Forests. Oxforshire: CABI Publishing; 2002; 77-92. [36] Vesk PA, Westoby M. Sprouting ability across diverse disturbances and vegetation types worldwide. J Ecol 2004;92(2):310-320.

[37] Harrington CA. Factors influencing initial sprouting of red alder. Can J For Res 1984;14:357-361.

[38] Burley J, Evans J, Youngquist J. Encyclopedia of forest sciences. Amsterdam: Elsevier;2004.

[39] Weigel DR, Peng CYJ. Predicting stump sprouting and competitive success of five oak species in southern Indiana. Can J For Res 2002;32(4):703-712.

[40] Sands BA, Abrams MD. Effects of stump diameter on sprout number and size for three oak species in a Pennsylvania clearcut. North J Appl For 2009;26(3):122-125.

[41] Wilson BF. Red maple stump sprouts: development the first year. Harvard Forest Paper No. 18. Petersham, MA: Harvard University; 1968.

[42] Matula R, Svátek M, Kůrová J, Úradníček L, Kadavý J, Kneifl M. The sprouting ability of the main tree species in Central European coppices: implications for coppice restoration. Eur J For Res 2012; 131(5):1501-1511.

[43] Johnson PS, Shifley SR, Rogers R. The ecology and silviculture of oaks. New York: CABI Publishing;2002.

[44] Clarke PJ, Lawes MJ, Midgley JJ. Resprouting as a key functional trait in woody plantschallenges to developing new organizing principles. New Phytol 2010;188(3): 651-654.

[45] Bond WJ, Midgley JJ. Ecology of sprouting in woody plants: the persistence niche. Trends Ecol Evol 1001;16(1):45-51. 
[46] Sjölund MJ, Jump AS. The benefits and hazards of exploiting vegetative regeneration for forest conservation management in a warming world. Forestry 2013;86:503-513.

[47] Motta R, Berretti R, Dotta A, Motta Fre V, Terzuolo P. Il governo misto. Sherwood - Foreste ed Alberi Oggi 2015;211:9-13.

[48] Corcuera L, Camarero JJ, Sisò S, Gil-Pelegrin E. Radial-growth and wood-anatomical changes in overaged Quercus pyrenaica coppice stands: functional responses in a new Mediterranean landscape. Trees 2006;20:91-98.

[49] Di Filippo A, Alessandrini A, Biondi F, Blasi S, Portoghesi L, Piovesan G. Climate change and oak growth decline: dendroecology and stand productivity of a Turkey oak (Quercus cerris L.) old stored coppice in central Italy. Ann For Sci 2010;67:706-706. 


\section{Figure captions}

Fig. 1 - Distribution of beech in Piedmont, Italy (blue) and beech coppice stands analyzed by this study (red dots)

Fig. 2 - Mean resprout age, maximum resprout height, and current canopy cover as a function of time since coppicing

Fig. 3 - Relationship between residual shoot density and (a) proportion of sprouting stools or (b) maximum resprout height in each plot $(\mathrm{n}=24)$

Fig. 4 - Relationship between site fertility and number of resprouts per stool (a) $(n=509)$ or maximum resprout height $(\mathrm{b})(\mathrm{n}=249)$

Fig. 5 - Marginal effects of significant predictors in the GLMM for the probability of sprouting (binomial regression with log link); in each panel, all other predictors were kept at their mean level

Fig. 6 - Predicted probability of sprouting as a function of mean cut diameter with or without uncut shoots, conditioned on fixed and random effects. Dots represent observed data.

Precipitation and age at time of coppicing were set at the average value for all plots

Fig. 7 - Marginal effects of significant predictors in the GLMM for maximum resprout height (lognormal regression with identity link); in each panel, all other predictors were kept at their mean level 
1

Fig. 8 - Predicted maximum resprout height as a function of time since coppicing and bedrock, conditioned on fixed and random effects. Dots represent observed data.

Precipitation was set at the average value for all plots 


\section{Tables}

Table 1 - Definition and units of variables used in this study

\begin{tabular}{|c|c|}
\hline Variable (units) & Description \\
\hline \multicolumn{2}{|l|}{ Descriptive } \\
\hline Tree density before coppicing $\left(\mathrm{ha}^{-1}\right)$ & $\begin{array}{l}\text { From local forest management } \\
\text { records }\end{array}$ \\
\hline Harvest intensity (\%) & $\begin{array}{l}100-\text { (Residual shoot density / Tree } \\
\text { density before coppicing) }\end{array}$ \\
\hline Resprouts $\left(\mathrm{ha}^{-1}\right)$ & $\begin{array}{l}\text { Shoots that we could confidently } \\
\text { classify as having sprouted after the } \\
\text { cut }\end{array}$ \\
\hline Number of stools $\left(\mathrm{ha}^{-1}\right)$ & Only including those that were cut \\
\hline Proportion of sprouting stools (\%) & $\begin{array}{l}\text { Stools with live or dead resprouts / } \\
\text { Number of stools (per plot) }\end{array}$ \\
\hline Number of resprouts per stool (-) & Resprouts / Number of stools \\
\hline Residual shoot density $\left(\mathrm{ha}^{-1}\right)$ & $\begin{array}{l}\text { From local forest management } \\
\text { records; includes all shoots but no } \\
\text { resprouts }\end{array}$ \\
\hline Fertility (ordinal 1 to 4 ) & From forest cover type map \\
\hline Resprout diameter (cm) & Measured at stump height \\
\hline Resprout origin (binary) & Root or shoot \\
\hline Resprout height $(\mathrm{cm})$ & Measured from stump height \\
\hline Resprout status (binary) & Dead or alive \\
\hline Mean resprout age (years) & $\begin{array}{l}\text { Average of ring counts from } 3-5 \\
\text { increment cores taken from each } \\
\text { resprout diameter class }\end{array}$ \\
\hline Resprout mortality rate (\%) & $\begin{array}{l}\text { Relative frequency of dead resprouts } \\
\text { (e.g., by competition or natural } \\
\text { disturbance), not including those } \\
\text { that had died and fallen from the } \\
\text { stool }\end{array}$ \\
\hline \multicolumn{2}{|l|}{ GLMMs - Dependent } \\
\hline Probability of sprouting $(0-1)$ & On each stool \\
\hline Height of the tallest resprout $(\mathrm{cm})$ & On each stool \\
\hline \multicolumn{2}{|l|}{ GLMMs - Independent } \\
\hline Age at time of coppicing (years) & $\begin{array}{l}\text { Average of tree ring counts from 3-5 } \\
\text { exposed stools per plot }\end{array}$ \\
\hline Time since coppicing (years) & From documental records \\
\hline Bedrock (categorical) & Limestone or granite \\
\hline Annual precipitation (mm) & From regional climate database \\
\hline Mean annual temperature $\left({ }^{\circ} \mathrm{C}\right)$ & From regional climate database \\
\hline Type of stool treatment (binary) & Total or partial cut \\
\hline \multicolumn{2}{|l|}{ Sum of the diameter of cut shoots $(\mathrm{cm})$} \\
\hline Average diameter of cut shoots $(\mathrm{cm})$ & \\
\hline Coefficient of variation of the diameter of cut shoots $(0-1)$ & \\
\hline
\end{tabular}


Table 2 - GLMM for probability of sprouting - summary of standardized coefficients.

Dispersion $=0.86$. Marginal $\mathrm{R}^{2}: 0.264$. Conditional $\mathrm{R}^{2}: 0.412$. St.dev. of random effects: 1.09 . $\mathrm{N}=479$ after deletion of missing cases

\begin{tabular}{lccc}
\hline & $\beta$ & Std. Error & $\mathrm{p}$-value \\
\hline intercept & -0.57 & 0.29 & 0.047 \\
Type of stool treatment: partial & 1.86 & 0.35 & $<0.001$ \\
average cut diameter & -0.37 & 0.15 & 0.012 \\
age at coppicing & 0.75 & 0.29 & 0.009 \\
precipitation & -1.01 & 0.28 & $<0.001$ \\
\hline
\end{tabular}

Table 3 - GLMM for height of tallest resprout - summary of standardized regression coefficients. Marginal $\mathrm{R}^{2}$ : 0.622 . Conditional $\mathrm{R}^{2}$ : 0.888 . St.dev. of random effects: $0.66 . \mathrm{N}$ $=242$ after deletion of missing cases.

\begin{tabular}{lccc}
\hline & $\beta$ & Std. Error & p-value \\
\hline intercept & 3.89 & 0.23 & $<0.001$ \\
time since coppicing & 1.03 & 0.17 & $<0.001$ \\
precipitation & -0.40 & 0.21 & 0.071 \\
bedrock: limestone & 0.93 & 0.43 & 0.046 \\
\hline
\end{tabular}


Figure 1
Click here to download high resolution image

Figure 1
Click here to download high resolution image

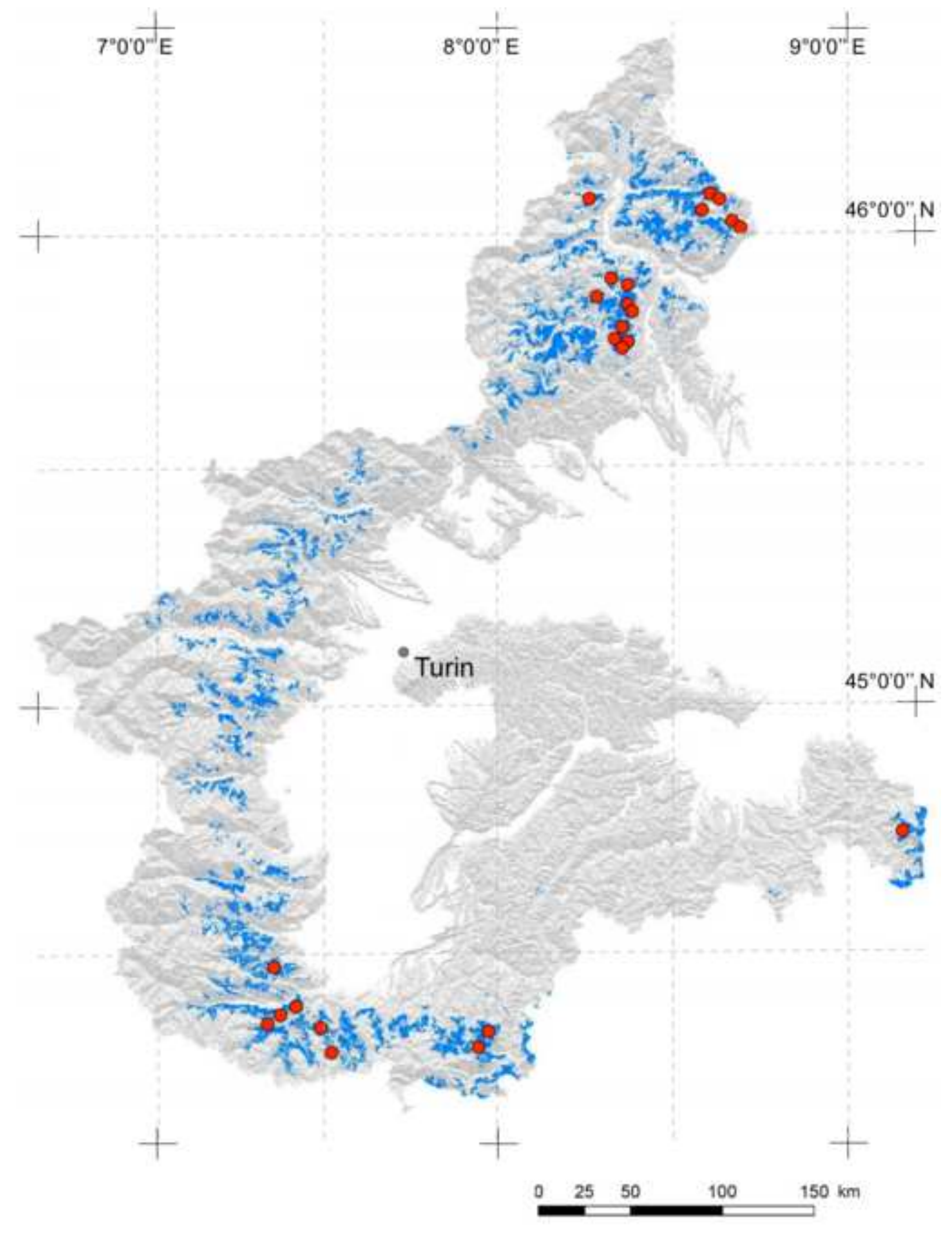

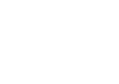

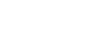


Figure 2
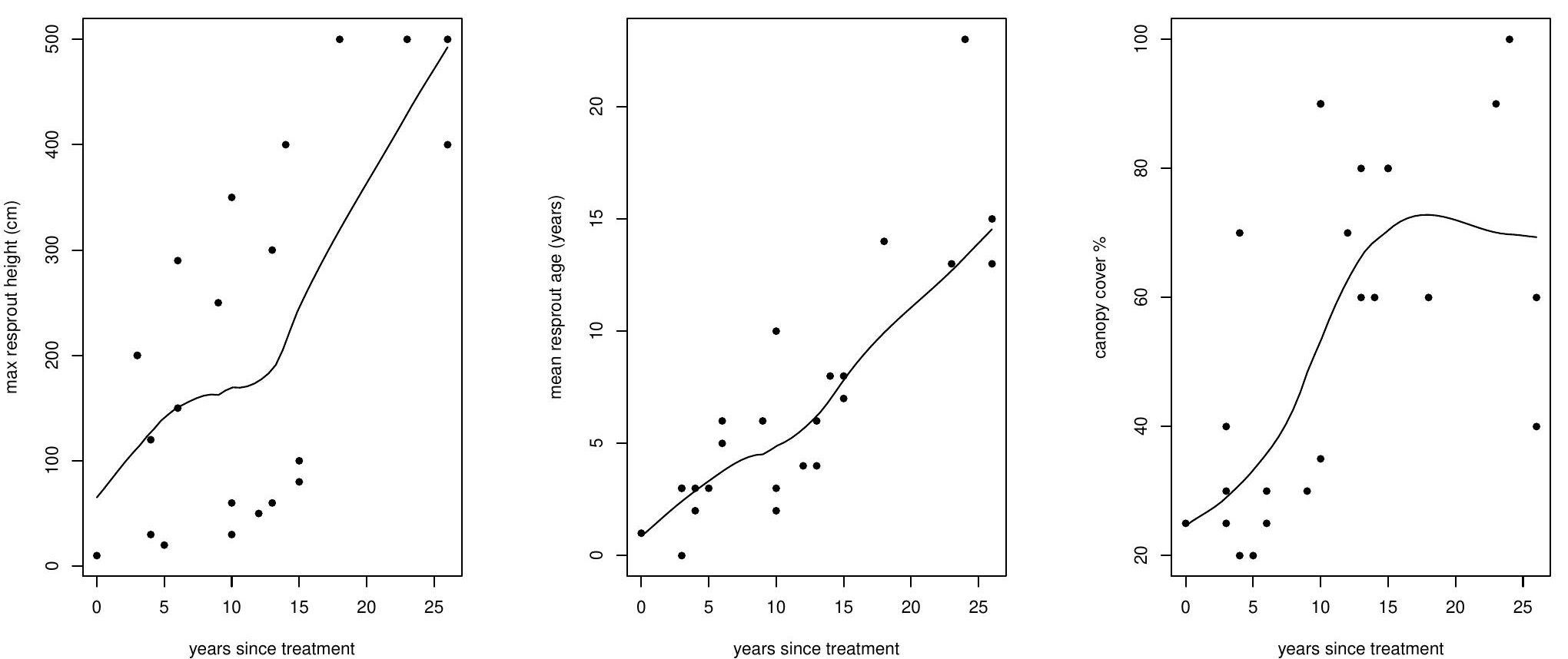
Click here to download high resolution image

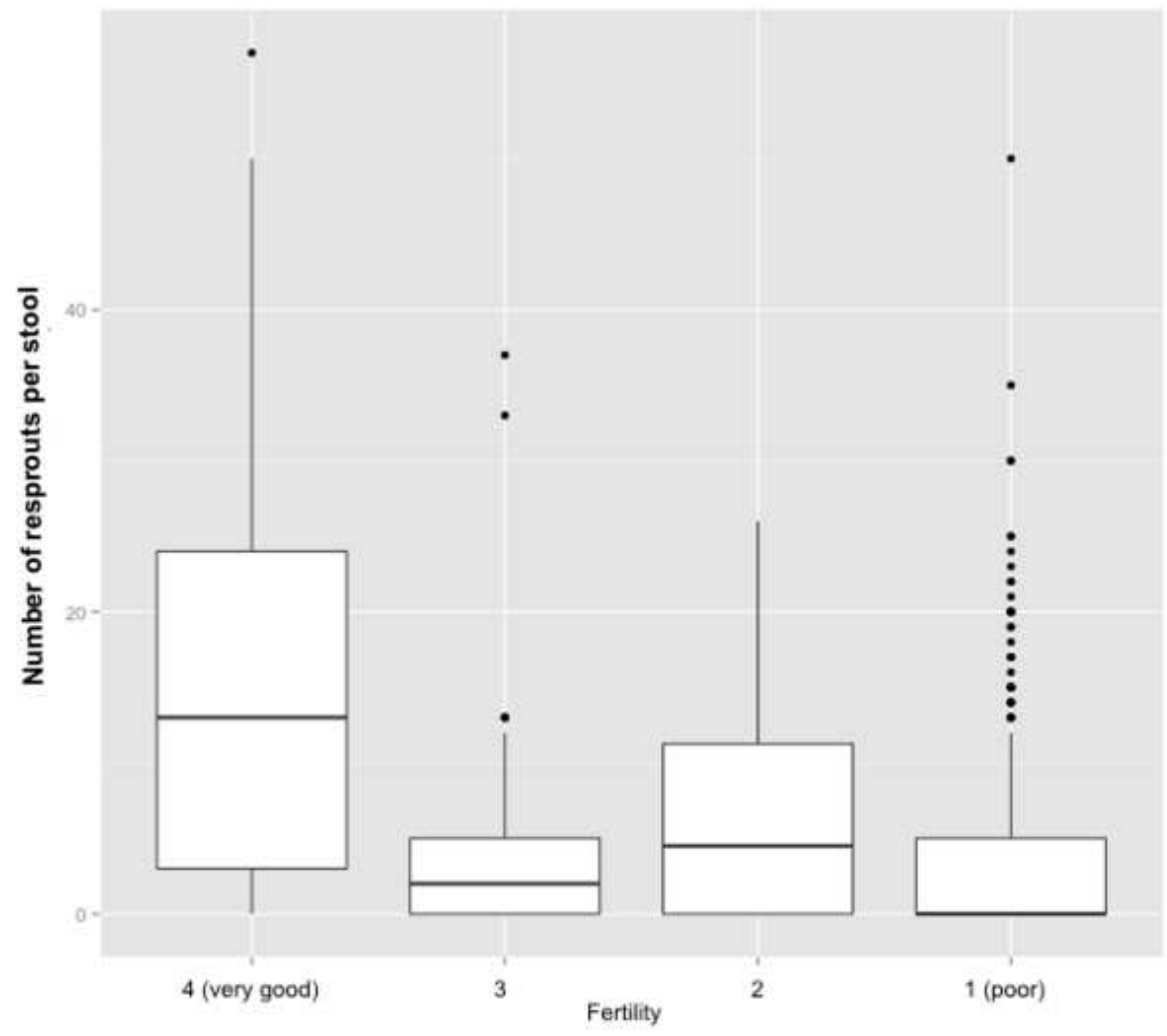


Click here to download high resolution image

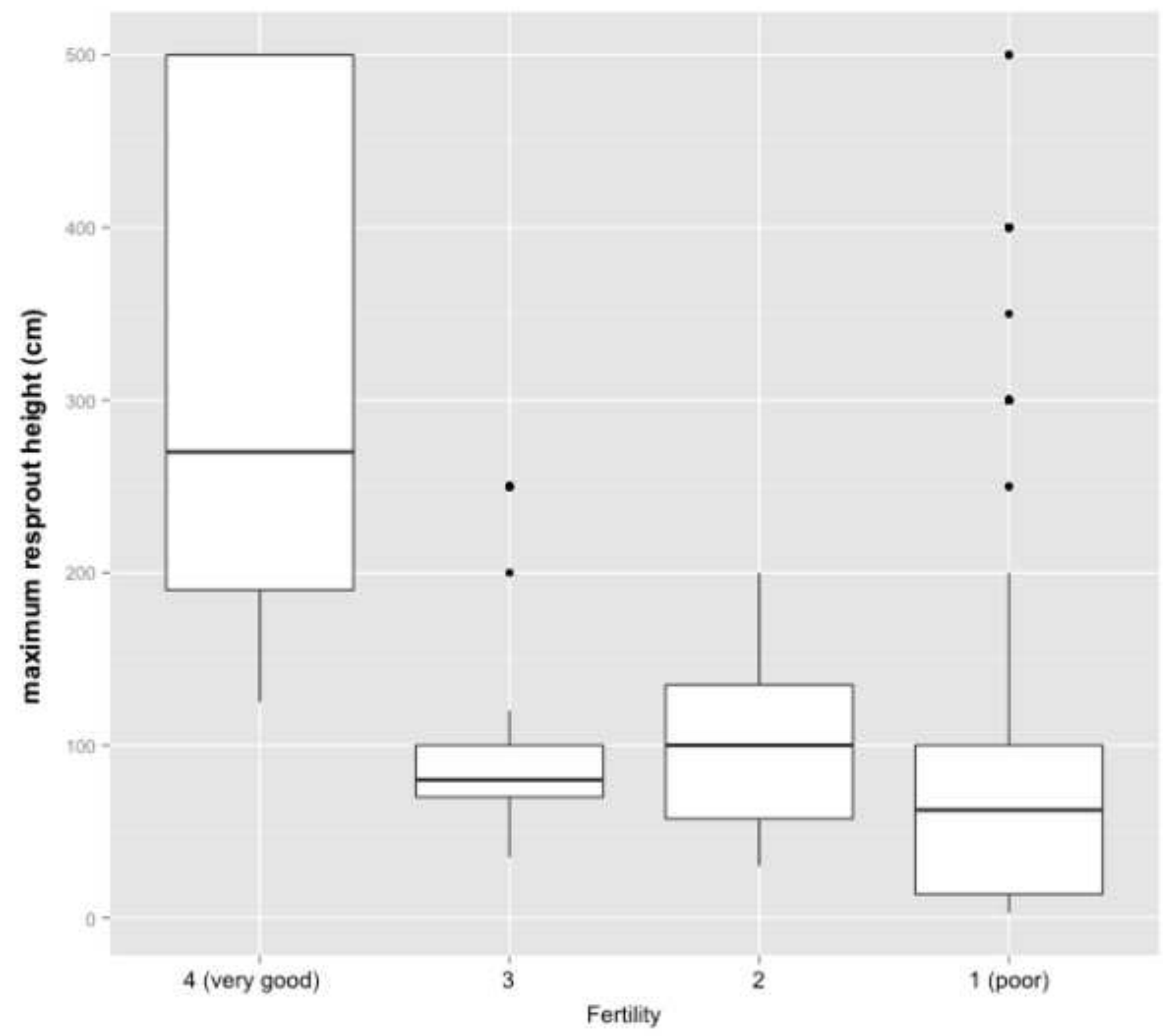




\section{Marginal effects of model predictors}

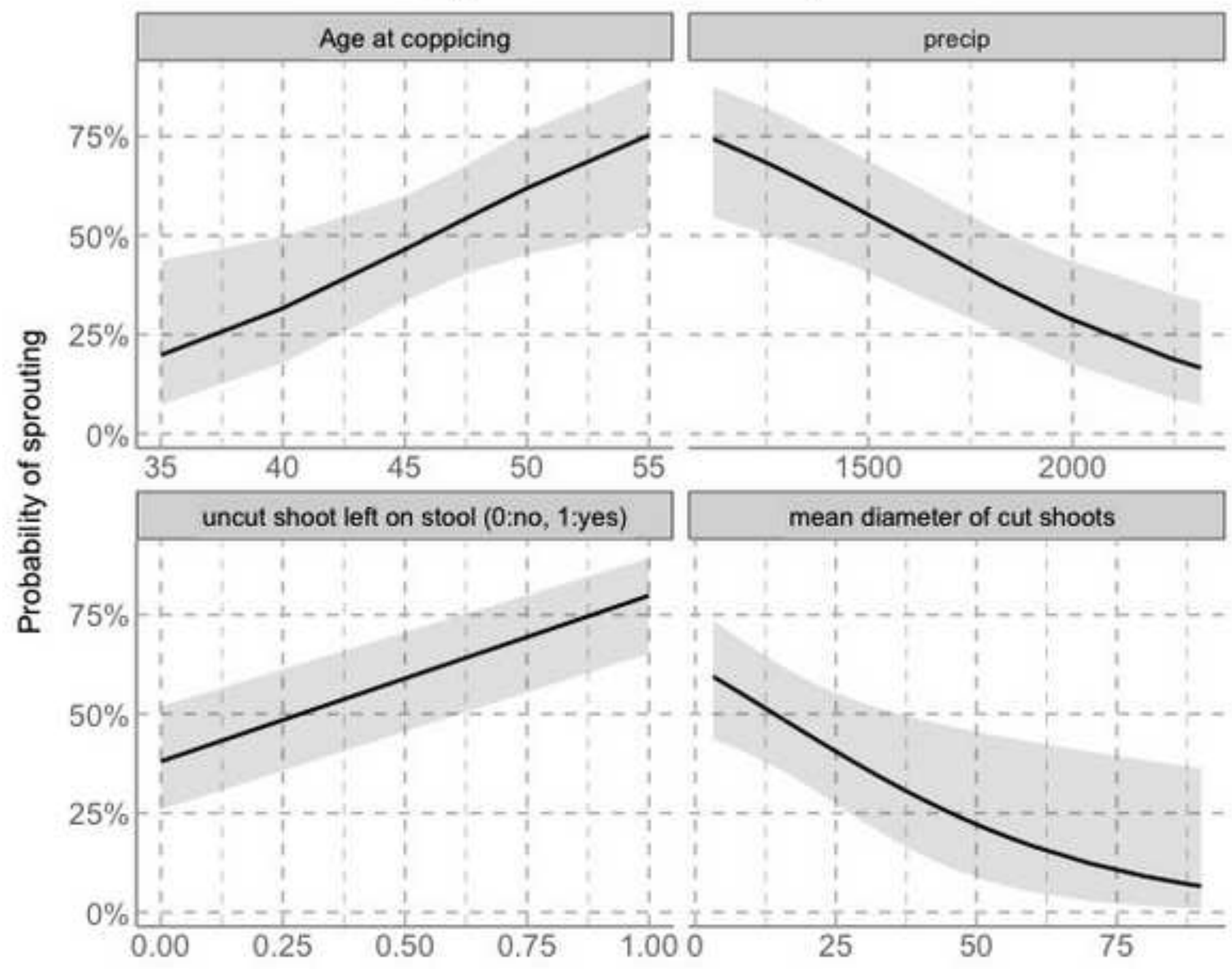


Click here to download high resolution image

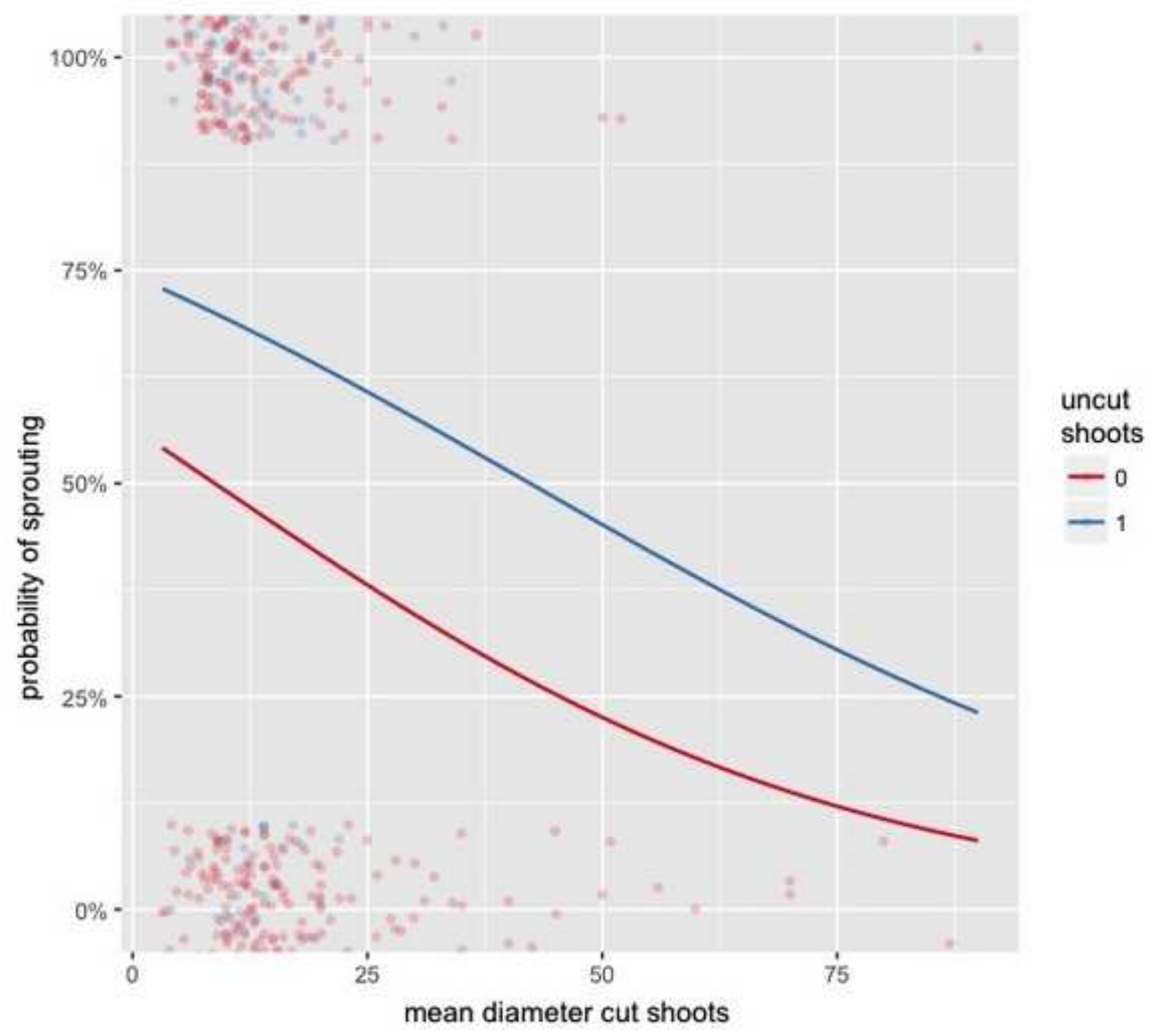


Marginal effects of model predictors

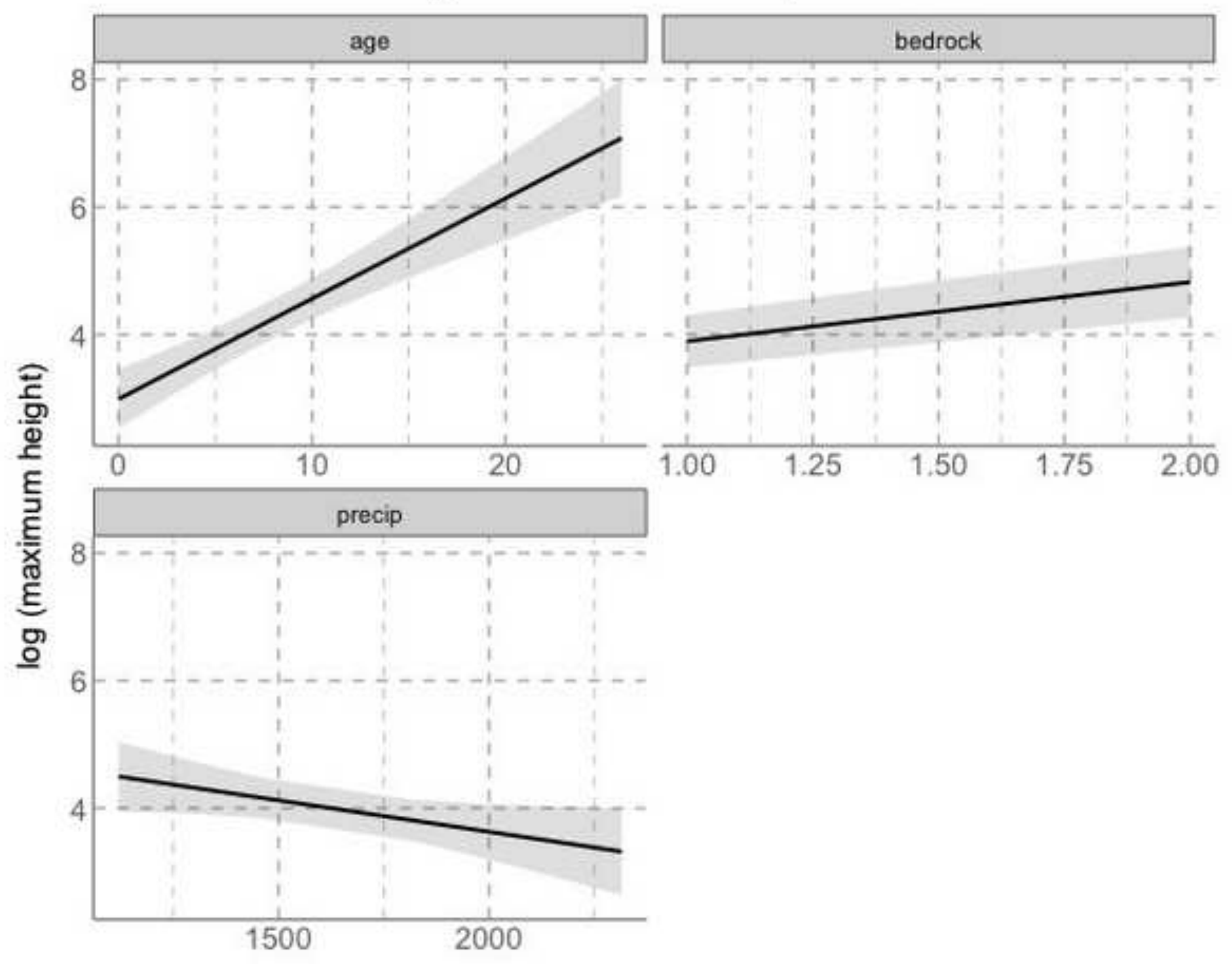




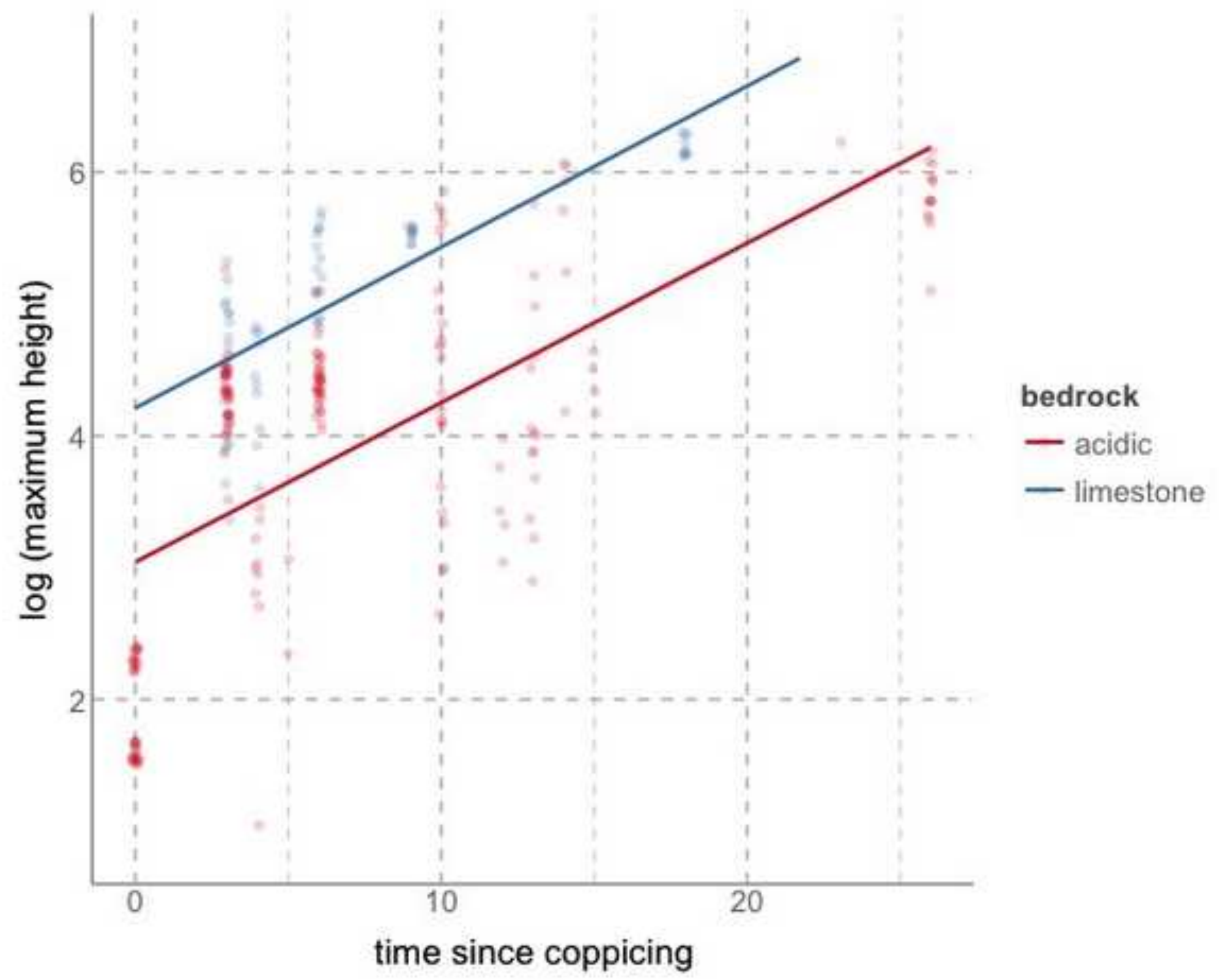

